\title{
PENGARUH ARUS LAUT TERHADAP SEBARAN TSS DI PERAIRAN RAROWATU UTARA KABUPATEN BOMBANA
}

\section{The Influence of Sea Flow to the Distribution of TSS in the North Rarowatu Waters of Bombana District}

\author{
Muhammad Saiful ${ }^{1}$, La Ode Muh. Yasir Haya ${ }^{2}$, A. Ginong Pratikino ${ }^{3}$ \\ ${ }^{1}$ Mahasiswa Jurusan Ilmu Kelautan, \\ Fakultas Perikanan dan Ilmu Kelautan, Universitas Halu Oleo. \\ Jl. H.E.A Mokodompit Kampus Hijau Bumi Tridharma Anduonohu Kendari 93232, Telp/Fax: (0401) 3193782 \\ ${ }^{2}$ Surel: lmyasir.haya@gmail.com \\ ${ }^{3}$ Surel: asringinong@gmail.com
}

\begin{abstract}
Abstrak
Penyebaran TSS di perairan pantai dan estuari dipengaruhi oleh pola arus pasang surut. Penelitian ini bertujuan untuk mengetahui bentuk pola arus, sebaran TSS dan untuk mengetahui hubungan pola arus dan sebaran TSS di Rarowatu Utara Kabupaten Bombana. Pengambilan data lapangan meliputi pengukuran arus menggunakan current meter, pengukuran pasang surut, dan pengambilan sampel air TSS. Hasil pengukuran arus yang diperoleh yaitu kecepatan arus rata-rata pada saat pengukuran di lokasi stasiun adalah $0,611 \mathrm{~m} / \mathrm{s}$ dengan arah arus dominan ke arah barat laut. Kecepatan arut tertinggi terdapat pada stasiun $\mathrm{V}$ dengan kecepatan arus $0,111 \mathrm{~m} / \mathrm{s}$ dan kecepatan arus terendah didapatkan pada stasiun IV dengan kecepatan arus yaitu $0.093 \mathrm{~m} / \mathrm{s}$. Nilai rata-rata kandungan TSS pada saat pasang yaitu $22,15 \mathrm{mg} / \mathrm{l}$. Hasil pengukuran TSS tertinggi berada pada stasiun IV yaitu $24,6 \mathrm{mg} / \mathrm{l}$ sedangkan hasil pengukuran terendah pada stasiun III yaitu $15,4 \mathrm{mg} / \mathrm{l}$. Sebaran TSS sangat dipengaruhi oleh pola arus dimana kecepatan arus yang tinggi dan cenderung mengarah ke barat laut menyebabkan konsentrasi sedimen tersuspensi terakumulasi di dekat dengan garis pantai dan estuari.
\end{abstract}

Kata Kunci: arus, pasang surut, TSS, perairan Rarowatu Utara

\begin{abstract}
Distribution of TSS is strongly influenced by the patterns of tidal current in coastal area and estuary. This study aimed to determine patterns of seacurrent, TSS distribution and the corelation between seacurrent patterns and TSS distribution in North Rarowatu of Bombana. Current velocity measurements, tide measurements, and water sampling for TSS were conducted in location. Result showed that the average of current velocity was $0.611 \mathrm{~m} / \mathrm{s}$ which heading to the northwest dominantly. The highest current velocity was found at station $\mathrm{V}$ with $0.111 \mathrm{~m} / \mathrm{s}$ while the lowest was at station IV with $0.093 \mathrm{~m} / \mathrm{s}$. The average of TSS content was $22.15 \mathrm{mg} / \mathrm{l}$ occuring at high tide. The highest TSS was at station IV with 24.6 $\mathrm{mg} / \mathrm{l}$ while the lowest was at station III with $15.4 \mathrm{mg} / \mathrm{l}$. The distribution pattern of TSS was strongly affected by seacurrent patterns. The high current velocity heading to the northwest caused the TSS concentration to accumulate near the coastline and estuary.
\end{abstract}

Keywords: current, tide, TSS, North Rarowatu seawaters

\section{Pendahuluan}

Total Padatan Tersuspensi (Total Suspended Solid/TSS) adalah bahan bahan tersuspensi (berdiameter $>1 \mu \mathrm{m}$ ) yang tertahan pada saringan miliopore dengan diameter pori $0.45 \mu \mathrm{m}$. TSS terdiri dari lumpur dan pasir halus serta jasad-jasad renik. Kandungan TSS utama di perairan ialah kikisan tanah atau erosi tanah yang terbawa ke badan air. Konsentrasi TSS apabila terlalu tinggi akan menghambat penetrasi cahaya ke dalam air dan mengakibatkan terganggunya proses fotosintesis. Penyebaran TSS di perairan pantai dan estuari dipengaruhi oleh beberapa faktor fisik antara lain angin, curah hujan, gelombang, arus, dan pasang surut
(Effendi, 2003). Metode konvensional yang sering digunakan dalam pengukuran TSS ialah metode Gravimetri.

Arus adalah gerakan mengalir suatu massa air yang disebabkan oleh tiupan angin, perbedaan densitas, atau pergerakan gelombang panjang. Pada masa sekarang ini arus laut banyak dimanfaatkan untuk berbagai keperluan yang menunjang kehidupan manusia. Selain itu, penelitian tentang arus pasang surut di perairan dapat memberikan pengaruh terhadap wilayah pesisir dan laut (Dijkstra, 2008).

Terjadinya arus dikarenakan tingginya perubahan permukaan air laut akibat pasang 
surut. Karakteristik arus pasang surut mempunyai periode yang tetap dan mengikuti pola pasang surut. Oleh karena itu, arus pasang surut terbagi dalam tiga tipe yaitu arus pasang surut diurnal, semi-diurnal, dan campuran (Fadilah, 2013).

Keberadaan arus pasang surut menyebabkan adanya pola sebaran Total Suspended Solid (TSS). TSS merupakan salah satu parameter yang mengindikasikan laju sedimentasi dan juga berupa zat padat (pasir, lumpur, dan tanah liat) atau partikel tersuspensi dalam air dan dapat berupa komponen hidup (biotik) seperti fitoplankton, zooplankton, bakteri, fungi ataupun komponen mati (Siswanto, 2010).

Berdasarkan posisi geografisnya, Kecamatan Rarowatu Utara memiliki batas batas yaitu di sebelah Utara berbatasan dengan Kecamatan Lantari Jaya, sebelah Selatan berbatasan dengan Kecamatan Rarowatu, sebelah Timur berbatasan dengan Selat Tiworo, serta di sebelah Barat berbatasan dengan Kecamatan Matausu. (BPS Dalam angka 2018)

Berdasarkan uraian di atas, maka pentingnya dilakukan penelitian mengenai pengaruh arus terhadap sebaran TSS untuk mengetahui besaran dan hubungan besaran TSS dengan kecepatan arus yang terjadi di Perairan Rarowatu Utara, Kabupaten Bombana.

\section{Bahan dan Metode}

Penelitian ini dilaksanakan selama tiga bulan yaitu pada bulan Februari sampai Mei 2019. Penelitian ini dilaksanakan melalui dua tahap, yaitu pengambilan data lapangan yang bertempat di perairan Rarowatu Utara, Kecamatan Rarowatu Utara, Kabupaten Bombana, Provinsi Sulawesi Tenggara (Gambar 1), dan analisis sampel TSS bertempat di Laboratorium Lingkungan Hidup Provinsi Sulawesi Tenggara.

Prosedur penelitian meliputi: survey pendahuluan, penentuan stasiun penelitian, pengambilan data lapangan, dan analisis laboratorium. Tahap survey pendahuluan dilakukan untuk mengetahui kondisi lokasi penelitian, penentuan titik stasiun dalam pengambilan sampel dan persiapan peralatan yang akan digunakan di lapangan.

Penentuan titik stasiun penelitian menggunakan metode purposive sampling. Berdasarkan survey pendahuluan yang telah dilakukan di perairan Rarowatu Utara, lokasi penentuan stasiun penelitian yaitu: Stasiun I, berada pada titik koordinat $\left(122^{\circ} 2^{\prime} 14,79^{\prime}\right.$ " BT - $4^{\circ} 43^{\prime} 31,13$ ” LS) dengan kondisi perairan yang berada di dekat pemukiman warga. Stasiun II, berada pada titik koordinat $\left(122^{\circ} 2\right.$ ' 11,56" BT - 4० 42' 59,96” LS) dengan kondisi perairan yang berada di sekitar hutan mangrove. Stasiun III, berada pada titik koordinat $\left(122^{\circ} 2^{\prime} 17,30^{\prime \prime} \mathrm{BT}-4^{\circ}\right.$ 42 ' 23,14" LS) dengan kondisi perairan yang berada di sekitaran tambak. Stasiun IV, berada pada titik koordinat $\left(122^{\circ} 2\right.$ ' 30,27" BT - $4^{\circ} 41^{\prime} 27,82^{\prime \prime}$ LS) dengan kondisi perairan yang berada di sekitaran tambak. Stasiun V, berada pada titik koordinat $\left(122^{\circ}\right.$ 2' 27,76" BT - 4'40'33,06" LS) dengan kondisi perairan yang berada di dekat tambak. Stasiun VI, berada pada titik koordinat $\left(122^{\circ}\right.$ 2' 11,98' BT - 4'39' 36,33' LS) dengan kondisi perairan yang berada di muara sungai.

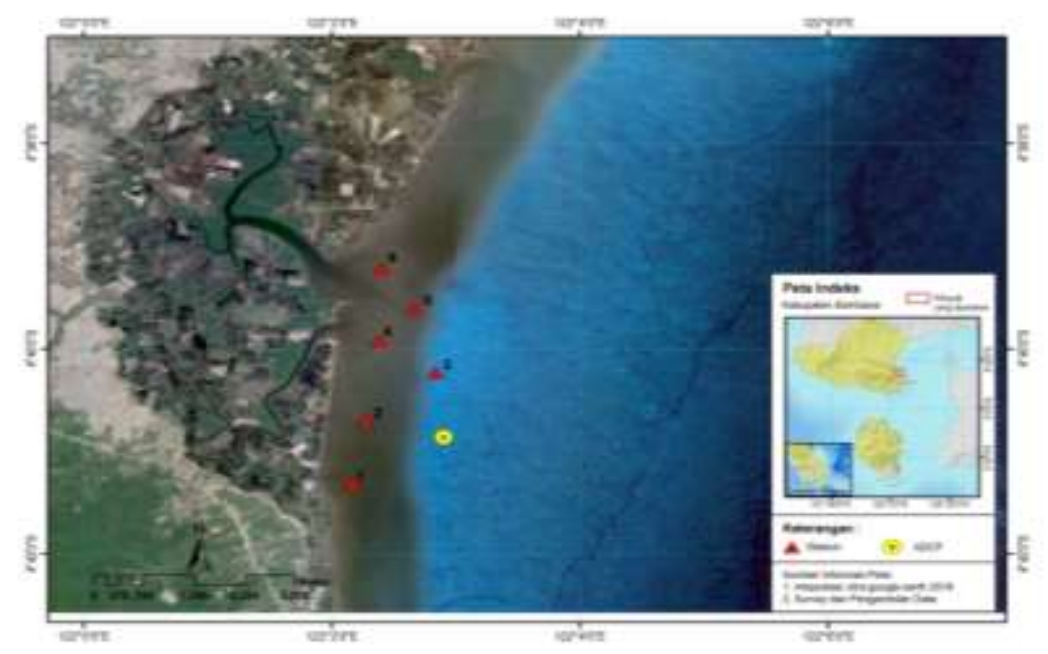

Gambar 1. Peta Lokasi Penelitian 
Pengukuran arus menggunakan current meter, Sistem kerja dari jenis current meter ini berdasarkan pada putaran propeller (balingbaling) yang digerakkan oleh aliran air. Selanjutnya putaran baling-baling dihubungkan langsung keroda-roda gigi/jarum penunjuk angka untuk mencari kecepatannya. Arah arus ditentukan dengan menggunakan kompas penunjuk arah yang terangkai secara mekanik dengan bantuan bola gotri kecil yang akan jatuh ke ruang arah arus melalui kompas penunjuk arah setiap pada putaran balingbaling tertentu. Sebagai contoh adalah alat ukur arus jenis "Current Meter". Sedangkan yang tidak berhubungan langsung ke baling baling yaitu dengan menggunakan sistem coupling magnetik. Biasanya yang menggunakan sistem inii adalah alat ukur arus jenis recording yang hasil rekamannya dapat berupa kertas grafik. Acoustic Doppler Current Meter (ADCM)

Pengukur arus jenis ini mirip dengan sistem kerja echosounder, tetapi yang dimanfaatkan adalah perubahan frekuensi suara yang dipantulkan balik ke alat akibat gerakan partikel air. Alat ukur ini dikenal dengan nama Acoustic Doppler Current Meter (ADCM) yang dapat dipasang baik di kapal maupun di dalam air dengan teknik tambatan. Yang diukur dari alat ini adalah kecepatan dan komponen arus arah timur barat, utara selatan dan atas bawah sehingga dari hasil komponen tersebut dapat ditentukan arahnya.

Prosedur yang digunakan dalam penelitian ini adalah metode deskritif. Metode deskritif merupakan suatu penelitian yang bermaksud mengadakan pemeriksaan dan pengukuran- pengukuran terhadap kondisi tertentu. Pengambilan data pasang surut menggunakan tiang berskala dengan pengkuran tinggi permukaan air laut, dilakuan tiap satu jam selama 28 hari.

Pengambilan sampel air TSS dilakukan pada kondisi pasang. Pengambilan sampel air tersebut menggunakan botol sampel dengan volume air sampel yang diambil sebanyak 600 $\mathrm{ml}$ dimasukan ke dalam botol sampel, selanjutnya dimasukan ke dalam cool box. Kemudian sampel dianalisis di laboratorium dengan uji TSS secara gravimetri menurut Badan Standardisasi Nasional 2004. Sampel air laut disaring dengan menggunakan kertas saring Whatman No. 42 dengan diameter 110 $\mathrm{mm}$. Setelah padatan tersuspensi tersaring pada kertas saring whatman, kemudian masukan kertas saring yang berisi padatan tersuspensi tersebut ke dalam oven pada suhu kisaran $103-105{ }^{\circ} \mathrm{C}$ selama 1 jam. Setelah proses pengeringan di dalam oven selesai, sampel didinginkan dalam desikator, lalu kertas saring ditimbang dengan timbangan analitik hingga memperoleh berat yang konstan. Selanjutnya kertas saring yang telah digunakan dan berisi residu dipanaskan seperti di atas dan ditimbang. Selisih antara berat kertas saring dengan residu terhadap berat kertas saring tanpa residu merupakan kandungan total zat padat tersuspensi.

\section{Analisis Data}

Menurut (Sugiyono, 2005) menyatakan bahwa metode deskriptif adalah suatu metode yang digunakan untuk menggambarkan atau menganalisis suatu hasil penelitian tetapi tidak digunakan untuk membuat kesimpulan yang lebih luas. Dapat dikatakan bahwa penelitian deskriptif merupakan penelitian yang berusaha mendeskripsikan suatu gejala, peristiwa yang terjadi pada saat sekarang atau masalah aktual.

Metode penelitian untuk membuat gambaran mengenai situasi atau kejadian yang diteliti atau dikaji pada waktu terbatas dan tempat tertentu untuk mendapatkan gambaran tentang situasi dan kondisi secara local (Suryabrata, 1983). Pengambilan sampel menggunakan cara purposive sampling method yaitu mengambil sebagian kecil sampel air dari lokasi penelitian tetapi hasilnya mewakili kondisi perairan pada lokasi penelitian (Hadi, 1979). Sampel yang telah diambil akan dianalisa laboratorium untuk mengetahui nilai konsentrasi TSS. Pengukuran arus dilakukan dengan menggunakan current meter.

Untuk menghitung pasang surut air laut dihitung menggunakan rumus oleh (Yuwono, 1994) sebagai berikut :

$F=\frac{A K 1+A O 1}{\mathrm{AM} 2+\mathrm{AS} 2}$

Keterangan:

$\mathrm{F}=$ Angka Pasang Surut ( bilangan Formzal)

$A K 1=$ Amplitudo dari komponen pasang surut K1

$A O 1=$ Amplitudo dari komponen pasang surut $\mathrm{O} 1$

$A M 2$ = Amplitudo dari komponen pasang surut M2

$A S 2=$ Amplitudo dari komponen pasang surut S2 
Adapun kriteria atau nilai pasang surut adalah sebagai berikut :

$\mathrm{F} \leq 0.25=$ Pasang surut harian ganda

(semi diurnal tide)

$\mathrm{F} \geq 3.00=$ Pasang surut harian tunggal

(diurnal tide)

$0.25<\mathrm{F}<1.50=$ Pasang surut campuran condong harian ganda

$1.50<\mathrm{F}<3.00=$ Pasang surut campuran condong harian tunggal

Analisis sampel total suspended solid menggunakan metode Gravimetri, dimana untuk mengetahui sebaran nilai TSS diperairan, maka sampel yang diperoleh dianalisis dengan rumus menurut Badan Standardisasi Nasional (2004) :

$\mathrm{TSS}=\frac{(\mathrm{A}-\mathrm{B}) \mathrm{X} 1000)}{\mathrm{V}}$

Keterangan:

TSS $=$ Total Suspended Solid (mg/l)

$\mathrm{A}=$ berat kertas saring + residu kering $(\mathrm{mg})$

$\mathrm{B}=$ berat kertas saring $(\mathrm{mg})$

$\mathrm{V}=$ volume contoh (l)

Dari beberapa parameter pengukuruan Kemudian data tersebut diolah menggunakan Microsoft office excel. Pengolahan dan analisis data arus ini kemudian dibuat dalam bentuk grafik, dan current rose menggunakan program World Currents 1.03 yang di jalankan pada software untuk menggambarkan pola arus yang terjadi sedangkan untuk melihat dominansi arah arus menggunakan software WindroseProb. Data yang diperoleh ditabulasi dan diolah dengan Microsoft Excel. Untuk mengetahui distribusi spasial total padatan tersuspensi tersebut menggunakan perangkat lunak ArcGis 10.3.

Pengolahan data dilakukan dengan menggunakan Analisis korelasi (Microsoft Excel), antara faktor kecepatan arus terhadap TSS. Menurut Sugiyono (2010), tingkat hubungan nilai Indeks korelasi dinyatakan sebagaimana pada Tabel 2 .

Tabel 1. Hubungan nilai indeks korelasi

\begin{tabular}{cc}
\hline Interval & Tingkat \\
Koefisien & Hubungan \\
\hline $0,00-0,199$ & Sangat lemah \\
$0,20-0,399$ & Lemah \\
$0,40-0,599$ & Sedang \\
$0,60-0,799$ & Kuat \\
$0,80-1,00$ & Sangat kuat \\
\hline
\end{tabular}

\section{Hasil Dan Pembahasan}

Arus

Arus adalah suatu gerakan air yang mengakibatkan perpindahan horizontal massa air. Berdasarkan hasil pengukuran dan pemodelan data, dapat dinyatakan bahwa pola arus di lokasi penelitian dalah didominasi pada saat surut menuju pasang. Berdasarkan gambar di atas arah arus dominan menuju arah Barat pada saat pasang dengan demikian pola pergerakan arus di perairan perairan Rarowatu Utara dipengaruhi oleh pasang surut.

Hasil pengukuran arus di lapangan diperoleh nilai kecepatan dan arah arus yang beragam pada setiap stasiun yaitu kecepatan arus rata-rata pada saat pengukuran di lokasi stasiun adalah $0,611 \mathrm{~m} / \mathrm{s}$ dengan arah arus dominan kearah barat laut. Kecepatan arus tertinggi yang didapatkan pada stasiun 5 dengan kecepatan arus $0,111 \mathrm{~m} / \mathrm{s}$ dan kecepatan arus terendah didapatkan pada stasiun 4 dengan kecepatan arus yaitu 0.093 $\mathrm{m} / \mathrm{s}$.

Nilai kecepatan arus semakin berkurang seiring bertambahnya kedalaman. Hal tersebut disebabkan oleh adanya pengaruh gaya gesekan dasar sehingga mempengaruhi kecepatan arus di dasar perairan. Sedangkan kecepatan arus di permukaan dipengaruhi oleh angin sehingga kecepatan arus di permukaan besar cenderung lebih cepat (Sugianto dan Agus, 2007).

Data kecepatan arus lapangan diperoleh melalui alat pengukuran current meter. Kemudian data tersebut diolah menggunakan Microsoft Office excel. Dari hasil perhitungan diperoleh hasil arus dari tiap stasiun didapatkan hasil pada stasiun pertama yaitu kecapatan 0.102 dengan nilai arah arus $283^{\circ}$ mengarah kearah barat, stasiun dua yaitu kecapatan 0.1 dengan nilai arah arus 298 mengarah kearah barat, stasiun tiga yaitu kecapatan 0.105 dengan nilai arah arus 267 mengarah kearah barat, stasiun empat yaitu kecapatan 0.093 dengan nilai arah arus 279 mengarah kearah barat, stasiun lima yaitu kecapatan 0.111 dengan nilai arah arus 285 mengarah kearah barat, dan stasiun dua yaitu kecapatan 0.1 dengan nilai arah arus 264 mengarah kearah barat, dengan rata rata kecepatan arus saat pasang yaitu $0,611 \mathrm{~m} / \mathrm{s}$ ditabulasi menggunakn software ArcGis 10 untuk mengetahui arah arus (Gambar 2). 
Tabel 2. Kecepatan arus

\begin{tabular}{|c|c|c|c|c|c|c|}
\hline \multirow{2}{*}{ stasiun } & \multicolumn{4}{|c|}{} & \multicolumn{3}{|c|}{ kecepatan $\mathrm{m} / \mathrm{s}$} & \multirow{2}{*}{ arah } \\
\cline { 2 - 6 } & $\mathrm{x}$ & $\mathrm{Y}$ & maksimum & minimum & rata-rata & \\
\hline 1 & 122.047 & -4.7016 & 0.138 & 0.069 & 0.102 & 283 \\
\hline 2 & 122.062 & -4.6603 & 0.141 & 0.093 & 0.1 & 298 \\
\hline 3 & 122.086 & -4.6282 & 0.142 & 0.054 & 0.105 & 267 \\
\hline 4 & 122.092 & -4.6548 & 0.126 & 0.061 & 0.093 & 279 \\
\hline 5 & 122.076 & -4.6858 & 0.156 & 0.102 & 0.111 & 285 \\
\hline 6 & 122.059 & -4.7261 & 0.139 & 0.059 & 0.1 & 264 \\
\hline
\end{tabular}

Pengukuran pasang surut dilakukan pada daerah pesisir kecamatan rarowatu utara dengan waktu pengukuran 28 hari per satu jam, dengan menggunakan tiang berskala untuk mengetahui jumlah mulai pasang surut tiap jamnya. Setelah itu data pasang surut diolah dengan menggunakan metode admiralty menghasilkan komponen pasang surut yang akan digunakan untuk mengetahui nilai MSL (Mean Sea Level), LLWL (Lowest Low Water Level), HHWL (Highest High Water Level) dan tipe pasang surut berdasarkan bilangan Formzahl.

Setelah mendapatkan nilai komponen pasang surut (Mean Sea Level), LLWL (Lowest Low Water Level), HHWL (Highest High Water Level) kemudian diolah menggunakan software BPPT Pasut untuk mendapatkan peramalan grafik pasang surut dengan grafik dapat dilihat pada Gambar 3.

\section{Pasang Surut}

Pasang surut merupakan suatu fenomena pergerakan naik turunnya permukaan air laut secara berkala yang diakibatkan oleh kombinasi gaya sentrifugal dan gaya tarik menarik dari benda-benda astronomi terutama oleh matahari, bumi dan bulan. Pengaruh benda angkasa lainnya dapat diabaikan karena jaraknya lebih jauh atau ukurannya lebih kecil (Dronkers, 1964). Faktor non astronomi yang mempengaruhi pasang surut terutama di perairan semi tertutup (teluk) antara lain adalah bentuk pantai dan topografi dasar perairan (Bonauli,et al, 2016).

Nilai pengukuran pasang surut selama 28 hari pada perairan Rarowatu Utara yang telah didapatkan kemudian diolah dengan menggukana metode admiralty. Setelah didapatkan 9 komponen pasang surut kemudian data tersebut dimasukan kedalam software BPPT Pasut untuk melihat hasil ramalan pasang surut pada Perairan Rarowatu
Utara, dengan begitu didapatkan hasil ramalan pasang surut periran Rarowatu Utara pada tanggal 4 - 18 Februari 2019.

Hasil pengukuran pasang surut di lapangan diperoleh bilangan formzhal 0,65 dengan tipe pasut Mixed Tide Prevailing Semidiurnal. Dengan LLWL yaitu $-56 \mathrm{~cm}$, HHWL yaitu $478 \mathrm{~cm}$ dan nilai MSL yaitu 144 $\mathrm{cm}$. Sementara hasil pasut yang diperoleh saat pengambilan sampel TSS yaitu $247 \mathrm{~cm}$ kondisi pasang pada jam 15.00 WITA tanggal 25 Februari 2019 dan surut terendah diperoleh nilai $1.0 \mathrm{~cm}$ jam 09.00 WITA tanggal 9 Februari 2019. Pada saat pengukuran pasang surut air laut, keadaan perairan saat pengambilan sampel yaitu peralihan dari pasang ke surut, dimana keadaan arus laut dari arah darat menuju ke arah laut.

\section{$\underline{\text { Total Suspended Solid (TSS) }}$}

Total Suspended Solid (TSS) merupakan padatan yang tersuspensi di dalam air yang berupa bahan-bahan organik dan inorganik yang tidak terlarut dan tidak mengendap langsung, dapat disaring dengan kertas milipore yang berpori-pori. Materi yang tersuspensi memiliki dampak yang buruk terhadap kualitas air karena mengurangi penetrasi matahari kedalam badan air sehingga kekeruhan air meningkat dan menyebabkan gangguan pertumbuhan bagi makhluk hidup di perairan atau mengganggu kehidupan biota akuatik (Petrus Subarjo et al. 2018).

Pada saat pengambilan sampel TSS di lapangan kondisi pasang surut yang terjadi pada saat pasang menuju surut, dimana didapatkan ketingian pasang surut yaitu pada jam 14.00 yaitu $249 \mathrm{~cm}$, jam 15.00 yaitu 253 $\mathrm{cm}$, jam 16.00 yaitu $227 \mathrm{~cm}$, dan jam 17.00 yaitu $178 \mathrm{~cm}$. Didapatkan pasang tertinggi terjadi pada jam 15.00 yaitu dengan ketinggian 253 dan surut terendah terjadi pada jam 21.00 yaitu $11 \mathrm{~cm}$. 


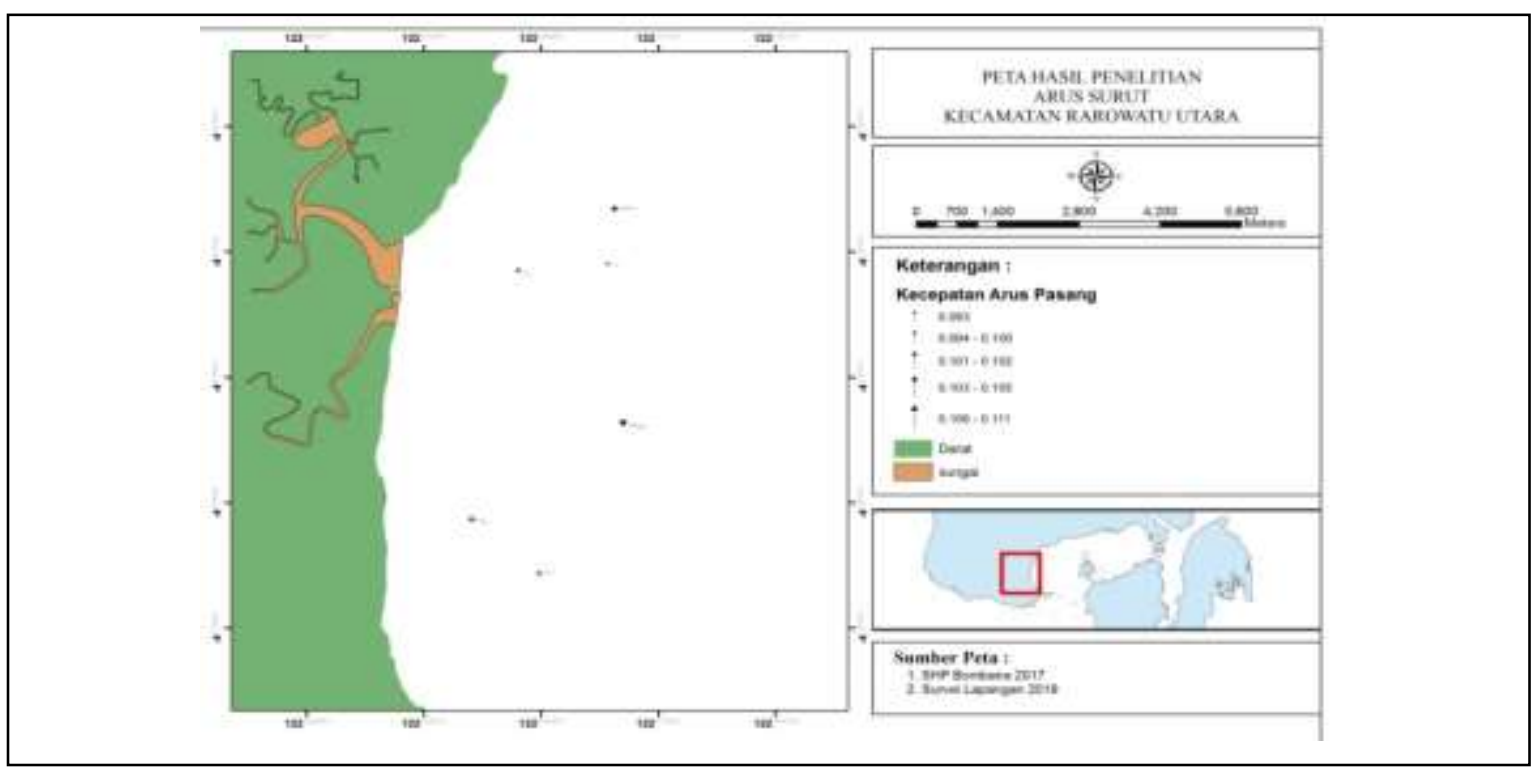

Gambar 2. Peta gambaran pola arus dan kecepatan arus saat pasang

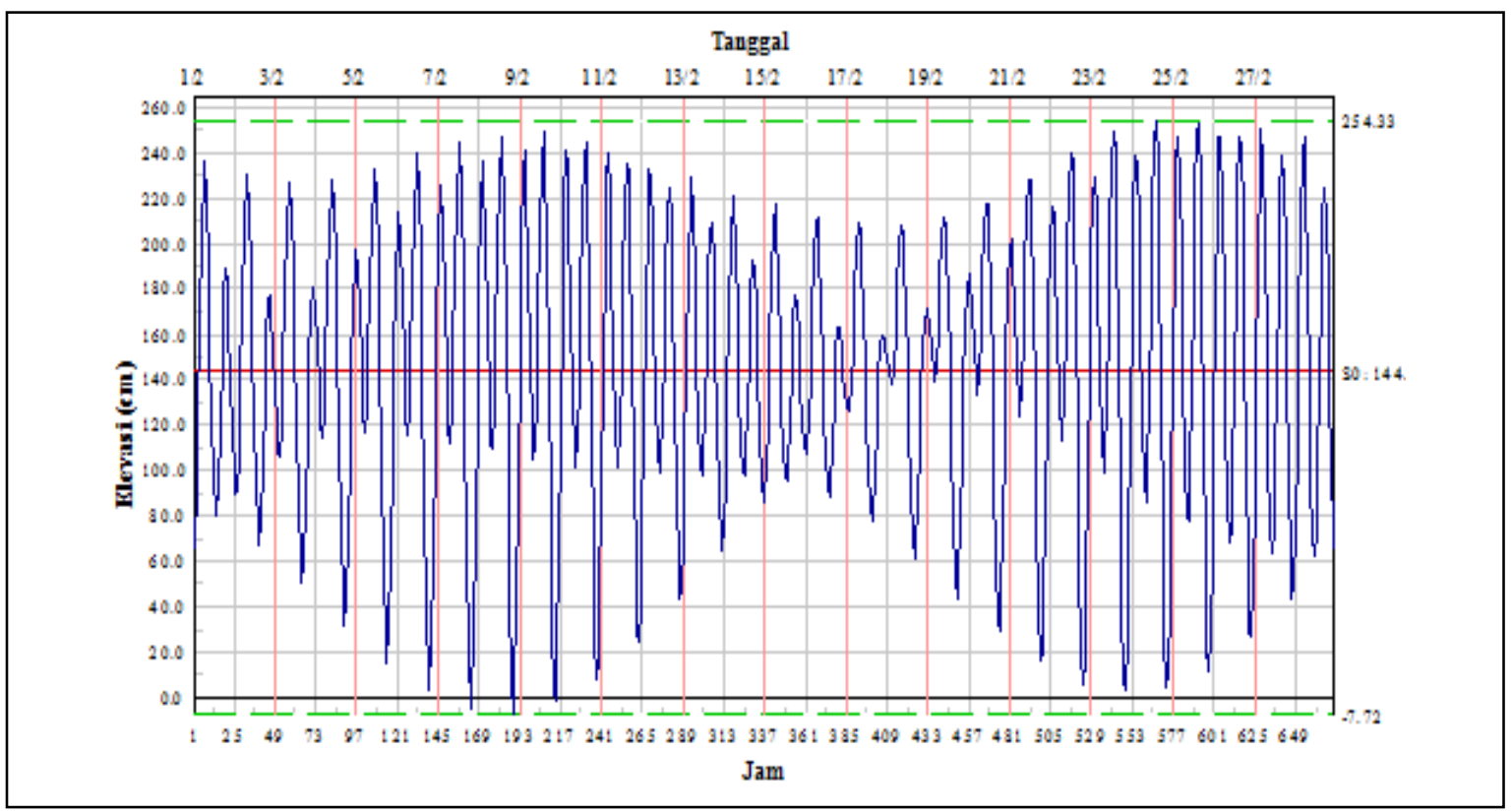

Gambar 3. Grafik ramalan pasang surut perairan Rarowatu Utara pada bulan Februari2019

Tabel 3. Komponen pasang surut Perairan Rarowatu Utara

\begin{tabular}{lcccccccccc}
\hline \multicolumn{10}{c}{ DATA KOMPONEN PASANG SURUT } \\
\hline & S0 & M2 & S2 & N2 & K1 & O1 & M4 & MS4 & K2 & P1 \\
\hline A Cm & \multirow{2}{*}{144} & 71 & 20 & 11 & 38 & 22 & 1 & 3 & 6 & 12 \\
$\mathrm{~g}^{\circ}$ & & 305 & 81 & 246 & 140 & 5 & 197 & 91 & 81 & 140 \\
\hline Tipe & 0.65 & \multicolumn{10}{c}{ Mixed Tide Prevailing Semidiurnal } \\
\hline
\end{tabular}

Z0 : 327

LLWL : $\quad-56$

HHWL : 478

MLWL : 236

MSL : 144 
Hasil analisis laboratorium sampel Total Suspended Solid (TSS) di Perairan Rarowatu Utara yang dilakukan saat pasang,menunjukan nilai kandungan TSS pada saat pasang yaitu pada stasiun I kandungan TSS 23,4 mg/l) dengan kondisi perairan yang berada di dekat pemukiman warga , satsiun II kandungan TSS 21,5 mg/l dengan kondisi perairan yang berada di sekitar hutan mangrove, stasiun III kandungan TSS $15,4 \mathrm{mg} / \mathrm{l}$ dengan kondisi perairan yang berada di sekitaran tambak, stasiun IV kandungan TSS 24,6 mg/l berada dengan kondisi perairan yang berada di sekitaran tambak, pada stasiun V kandungan TSS 23,7 $\mathrm{mg} / \mathrm{l}$ berada pada kondisi perairan dekat tambak, dan stasiun VI kandungan TSS 24,3 berada pada kondisi perairan dekat di muara sungai.

Table 4. Nilai total suspended solid

\begin{tabular}{|c|c|}
\hline STASIUN & TSS \\
\hline Stasiun I & 23.4 \\
\hline Stasiun II & 21.5 \\
\hline Stasiun III & 15.4 \\
\hline Stasiun IV & 24.6 \\
\hline Stasiun V & 23.7 \\
\hline Stasiun VI & 24.3 \\
\hline
\end{tabular}

Nilai rata-rata kandungan TSS saat pasang yaitu 22,15 mg/l pada perairan Kecamatan Rarowatu Utara. Kandungan TSS saat pasang dapat dilihat pada Gambar 6 berikut, dimana nilai rata-rata kandungan TSS saat pasang yaitu $22,15 \mathrm{mg} / \mathrm{l}$. Berdasarkan hasil pengukuran lapangan maka menunjukan nilai hasil pengukuran TSS tertinggi berada pada stasiun IV yaitu $24,6 \mathrm{mg} / \mathrm{l}$ hasil pengukuran lebih tinggi diakibatkan karena lokasi yang berada tepat pada Muara Sungai Rumbia dan untuk hasil pengukuran terendah pada stasiun III yaitu $15,4 \mathrm{mg} / \mathrm{l}$ hasil pengukuran sangat rendah diakibatkan karena lokasi pengukuran tepat berada pada daerah kedalaman.

Berdasarkan hasil pengukuran lapangan dan analisis laboratorium sampel TSS yang dilaksanakan di Laboratorium Lingkungan Hidup Provinsi Sulawesi Tenggara, menghasilkan nilai kandungan TSS saat pasang yang ditunjukkan pada gambar. Hasil nilai kandungan muatan padatan tersuspensi yang telah didapatkan tersebut diinterpretasikan dalam bentuk peta menggunakan software Arcgis, untuk memperoleh gambaran pola sebaran muatan padatan tersuspensi pada saat pasang.

Hasil analisis laboratorium sampel Total Suspended Solid (TSS) di perairan Rarowatu Utara yang dilakukan saat pasang.nilai ratarata kandungan TSS saat pasang yaitu 22,15 $\mathrm{mg} / \mathrm{l}$. Dari hasil pengukuran lapangan maka didapatkan nilai hasil pengukuran TSS tertinggi berada pada Stasiun IV yaitu 24,6 $\mathrm{mg} / \mathrm{l}$ dan untuk hasil pengukuran terendah pada Stasiun III yaitu 15,4 mg/l. dapat disimpulkan bawa nilai besaran TSS tertinggi berada di muara Sungai Rumbia diakibatkan terjadinya aktifitas sungai yang membawa partikelpartikel sedimen ke muara sungai sehingga didapatkan hasil pengukuran tertinggi pada muara Sungai Rumbia, sedangkan untuk nilai TSS terendah berada pada Stasiun III yang berada jauh dari muara sungai sehingga sangat kecil kemungknan untuk TSS ikut terbawah ke titik Stasiun III (Suyarso, 2008).

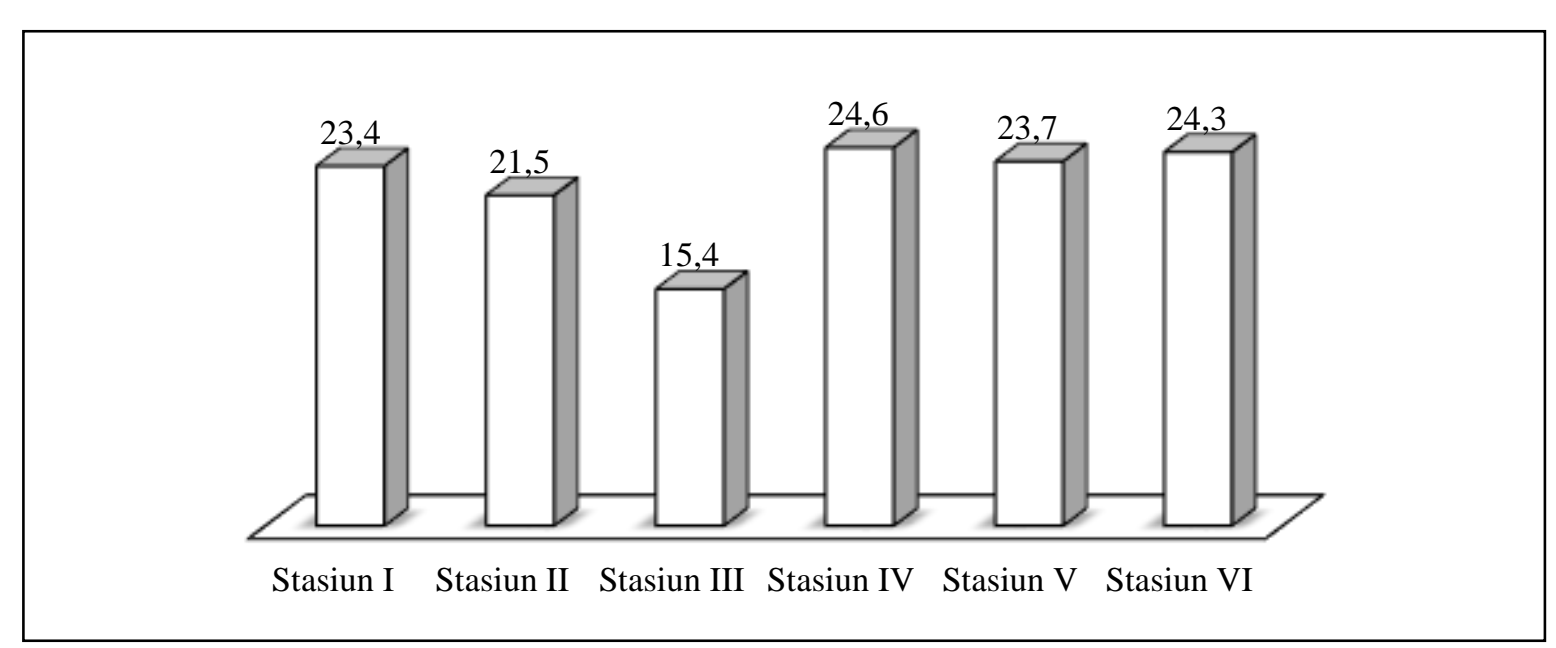

Gambar 5 . Grafik Kandungan Total Suspended Solid (TSS) dalam mg/l 


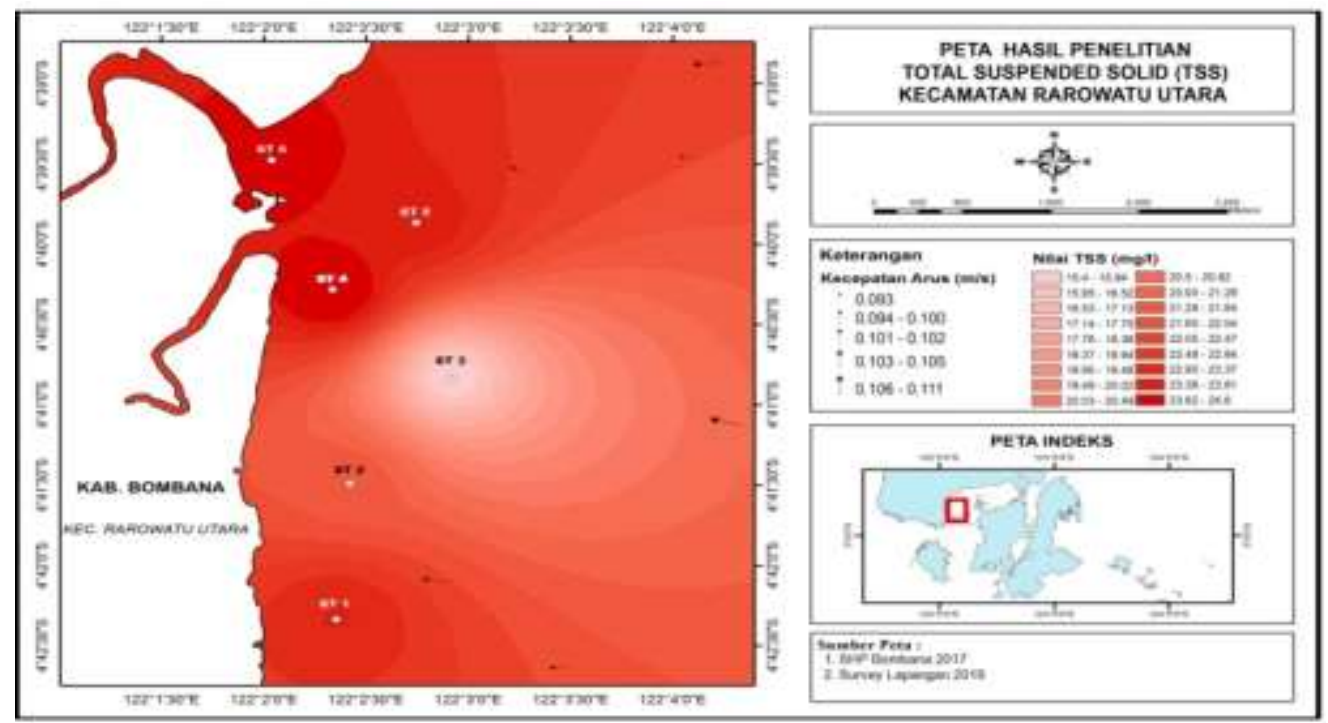

Gambar 6. Pola Sebaran Total Suspended Solid (TSS)

Berdasarkan Permen LHK NO.P.68 Tahun 2016 telah ditetapkan bahwa kadar baku mutu TSS adalah $30 \mathrm{mg} / \mathrm{l}$. jika lebih dari $30 \mathrm{mg} / \mathrm{l}$ maka dinyatakan tidak memenuhi baku mutu yang telah ditetapkan oleh Mentri LHK dan Kehutanan. Sehingga tdk memungkinkan untuk dilakukan proses budidaya laut dan sebagainya.

Umumnya tingkat kekeruhan atau kecerahan suatu perairan sangat dipengaruhi oleh kandungan zat padat suspensi. Pada perairan pantai, seperti perairan Rarowatu Utara, kekeruhan air sangat dipengaruhi oleh kontribusi suspensi dari sungai yang dibawa arus sepanjang pantai (longshore current) sehingga kecil kemungkinan dijadikan daerah penangkapan ikan dan budidaya rumput laut. Selain itu dipengaruhi pengadukan gelombang terhadap sedimen pantai, karena perairan Rarowatu Utara merupakan perairan estuari yang terdapat beberapa sungai bermuara di perairan ini. Namun kandungan zat padat tersuspensi di perairan ini tampaknya belumlah menyebabkan rendahnya tingkat kecerahan air laut.

\section{Hubungan Arus dan TSS}

Hasil simulasi memperlihatkan bahwa pergerakan arus di daerah Kecamatan Rawoatu Utara yaitu model kecil cenderung memiliki arah menuju ke daratan dengan kondisi perairan pasang yang terjadi saat pengukuran. Adapun gambaran pola penyebaran arus disajikan dalam bentuk pola arus seperti yang terlihat pada peta pada Gambar 6. Gambar 6 menunjukkan pola arus saat surut menuju pasang, dimana arus bergerak dari timur menuju ke barat. Pengukuran arus dilakukan dengan menggunakan alat Current meter pada 6 stasiun dilokasi berbeda pada daerah Kecamatan Rarowatu Utara Kabupaten Bombana, maka didapatkan hasil rata-rata pengukuran pada saat pengmbilan sampel yaitu pada pukul 14.00 sampai dengan 15.00 WITA didapatkan rata-rata hasil pengukuran pada stasiun 1 yaitu $0,102 \mathrm{~m} / \mathrm{s}$, stasiun 2 yaitu $0,100 \mathrm{~m} / \mathrm{s}$, stasiun 3 yaitu $0,105 \mathrm{~m} / \mathrm{s}$, stasiun 4 yaitu $0,093 \mathrm{~m} / \mathrm{s}$, stasiun 5 yaitu $0,111 \mathrm{~m} / \mathrm{s}$, dan stasiun 6 yaitu $0,100 \mathrm{~m} / \mathrm{s}$.

Dari hasil pengukuran diperoleh nilai TSS yang bervariasi pada masing-masing stasiun, yaitu pada stasiun I kandungan TSS 23,4 mg/l, satsiun II kandungan TSS 21,5 $\mathrm{mg} / \mathrm{l}$, stasiun III kandungan TSS 15,4 mg/l, stasiun IV kandungan TSS 24,6 mg/l, pada stasiun $\mathrm{V}$ kandungan TSS 23,7 mg/l dan stasiun VI kandungan TSS 24,3 mg/l, dimana nilai rata-rata kandungan TSS saat pasang yaitu $22,15 \mathrm{mg} / \mathrm{l}$

Data ini menunjuan bahwa perairan yang ada di Pesisir Kecamatan Rarowatu Utara mempunyai kualitas air yang ada masih memenuhi baku mutu yang ditetakan oleh KLHK, dimana nilai kadar baku mutu TSS adalah $30 \mathrm{mg} / \mathrm{l}$ dinyatakan memenuhi nilai baku mutu. jika lebih dari $30 \mathrm{mg} / \mathrm{l}$ maka dinyatakan tidak memenuhi baku mutu untuk budidya laut.

Hubungan antara arus dan TSS memiliki kaitan yang lemah, Hubungan ini lemah dikarenakan nilai korelasi antara TSS 
yaitu -0.30121 yang berkategori lemah menurut Sugiono (2010).

Berdasarkan peta sebaran Total Suspended Solid bahwa kecepatan arus yang tinggi mengakibatkan konsentrasi sedimen tersuspensi terindikasi didekat dengan garis pantai lebih tinggi dibandingkan stasiun lainnya. Hal ini sebaran sedimen di sekitar daerah tersebut terangkut oleh arus dan membuat perairan menjadi keruh, kemudian saat memasuki tepian pantai sedimen tersuspensi tersebut akan diendapkan dan dapat terjadi proses sedimentasi. Menurut Poerbandono dan Djunasjah (2005) sedimen yang berukuran kecil cenderung terangkut sebagai suspensi dimana kecepatan dan arahnya mengikuti kecepatan dan arah arus.

Arus mempengaruhi penyebaran TSS di perairan rarowatu Utara, Kabupaten Bombana. Hal ini dapat dilihat bahwa pola persebaran TSS dipengaruhi oleh arus pasang surut yang menjadi dominansi arus di perairan muara Sungai Rumbia.

Saat terjadi pasang, arus bergerak menuju ke arah daratan dan mengangkut sedimen tersuspensi dari laut ke arah daratan dan bertemu dengan arus dari hulu sungai yang mengangkut TSS di muara sungai sehingga nilai konsentrasi sedimen suspensi di muara sungai ditemukan tinggi.

Sebaliknya, saat kondisi surut konsentrasi TSS yang berada di muara sungai menyebar ke arah laut yang dipengaruhi oleh arus surut. Sebaran sedimen tersuspensi mengikuti pergerakan arus. Poerbandono dan Djunasjah (2005) menyatakan bahwa sedimen yang berukuran kecil cenderung terangkut sebagai suspensi yang di dalam hal ini kecepatan dan arahnya mengikuti kecepatan dan arah arus.

\section{Kesimpulan}

Berdasarkan uraian pada bagian sebelumnya, maka kesimpulan penelitian ini adalah sebagai berikut:

1. Arus laut yang dominan mempengaruhi konsentrasi sebaran TSS di perairan kecamatan Rarowatu Utara adalah arus pasang. Tingginya nilai konsentrasi sebaran TSS di perairan dasar dibandingkan di permukaan karena adanya resuspensi sedimen dan pergerakkan arus di lapisan, kecepatan arus maksimum $0,156 \mathrm{~m} / \mathrm{s}$ pada arah $285^{\circ}$ berada di stasiun $\mathrm{V}$, sedangkan kecepatan arus minimum
$0,054 \mathrm{~m} / \mathrm{s}$ pada arah $267^{0}$ pada stasiun III. Secara umum kecepatan arus rata-rata di Perairan Rarowatu Utara adalah 0,111 pada arah $285^{\circ}$.

2. Nilai kandungan TSS tertinggi ditemukan pada Stasiun IV dengan kosentrasi 24,6 $\mathrm{mg} / \mathrm{l}$ pada titik koordinat $\left(122^{\circ} 2^{\prime} 30,27^{\prime}\right.$ ' BT - $4^{\circ} 41^{\prime} 27,82$ ” LS) sementara nilai kandungan TSS terendah yaitu pada Stasiun III dengan konsentrasi 15,4 mg/l.

3. Hubungan antara arus dan TSS memiliki hubungan yang lemah dikarenakan nilai korelasi antara TSS yaitu -0.30121 yang berkategori lemah.

\section{Daftar Pustaka}

Brata, Sumadi Surya. 1983. Metodologi Penelitian. Jakarta: Rajawali.

Dijkstra, A. 2008. Dynamical Oceanography. SpringerVerlag Berlin Heidelberg, German. 405 pp.

Effendi. H. 2003. Telaah Kualitas Air bagi Pengelolaan Sumberdaya dan Lingkungan Perairan. Penerbit Kanisius, Yogyakarta.

Fadilah, Suripin, Dwi P Sasongko . 2013. Menentukan Tipe Pasang Surut dan Muka Air Rencana Perairan Laut Kabupaten Bengkulu Tengah Menggunakan Metode Admiralty. Maspari Journal, 6 (1), 1-12.

Hadi, S. 1979. Metodologi Research. Penulis Paper, Skripsi, Thesis dan Disertasi .

Yayasan Penerbit Fakultas Psikologi UGM, Yogyakarta, $75 \mathrm{hlm}$.

Lanuru, M Dan Suwarni. 2011. Bahan Ajar Pengantar Oseonografi. Universitas Hasanuddin. Makassar.

Melissa Bonauli Helmi ,M dan S. Pranowo W., 2016. Analisis Karakteristik Arus Harmonikakibat Pasang Surut di Perairan Teluk Awur Kabupaten Jepara jurnal oseanografi. Volume 5, Nomor 1, Halaman $1-10$

Oktiarini,D., Atmodjo.,W. dan Widada, S. 2015. Transport Sedimen di Lokasi Perencanaan Pembangunan Pelabuhan Marunda, Jakarta Utara,. Jurnal oseanografi. Volume 4, Nomor (1), Halaman 325 - 332 Online di : http://ejournal-

s1.undip.ac.id/index.php/jose

Permana, S. D. Triyati E., Nontji, A., 1994. Pengamatan Klorofil dan Seston di 
Perairan : Evaluasi Kondisi Perairan

Selat Malaka, p. 63.

Poerbandono dan E. Djunasjah. 2005. Survei Hidrogafi. Refika Aditama, Bandung

Peraturan Menteri lingkungan hidup dan kehutanan republik indonesia nomor: P.68/Menlhk-Setjen/2016 Tentang Baku Mutu Air Limbah.

Rismanto,J. 2011.Studi Transport Sedimen di Pantai Kuta- Bali Melalui Pendekatan GENESIS. Jurusan Ilmu Kelautan. FakultasPerikanan dan Ilmu Kelautan. Universitas Diponegoro. Semarang. $168 \mathrm{hlm}$.

Siswanto, A.D. 2010. Kajian Sebaran Substrat Sedimen Permukaan Dasar di Perairan Pantai Kabupaten Bangkalan. Jurusan Ilmu Kelautan, Fakultas Pertanian, Universitas Trunojoyo Madura.

Surabaya.

Solihudin.Sari, M. E. dan Kusumah, G. 2011. Prediksi Laju Sedimentasi di di Perairan Pemangkat Sambas Kalimantan Barat Menggunakan Metode Permodelan. Jakarta. Buletin Geologi Tata Lingkungan. Vol. (21) No 3. $117-126$.

Subardjo P, AnugrohoDwi Suryo A,Pratikno I,Handoyo G ,(2018) DepartemenOseanografi, FakultasPerikanandan Ilmu Kelautan, Universitas Diponegoro Jl. Prof. Sudarto, SH, Tembalang, Semarang, Jawa Tengah, 50275.

Sugianto, D. N dan Agus ADS. 2007. Studi Pola Sirkulasi Arus Laut di Perairan Pantai Provinsi Sumatera Barat. Jurnal Ilmu Kelautan. UNDIP. Vol. 12 (2): 79 -92, p. 80 .

Sugiyono. 2010, Metode Penelitian Pendidikan, Penerbit Alphabet:Bandung

Suyarso. 2008. Perubahan Garis Pantai Muara Sungai Cisadane dan Sekitarnya, Tangerang, Banten. Oseanologi dan Limnologi di Indonesia. Jakarta.

Yuwono, Nur. 1994. Perancangan Bangunan Jetti, Laboratorium Hidrulika dan Hidrologi. PAU-ITUGM, Yogyakarta. 